\title{
Haemodialysis in Infants and Small Children
}

\author{
J. ANDERSON,* M.D., B.SC., F.R.C.P. ; H. A. LEE, $†$ M.B., B.S., B.SC., M.R.C.P. ; \\ C. E. STROUD, $\ddagger$ B.SC., D.C.H., M.R.C.P.
}

Brit. med. F., 1965, 1, 1405-1408

Extracorporeal haemodialysis is at present rarely used on infants and young children. Only seven infants under 2 years and 30 children under 15 years treated by haemodialysis have been reported in the past ten years (Merrill, Smith, Callahan, and Thorn, 1950 ; Mateer, Greenman, and Danowski, 1955 ; Carter, Aoyama, Mercer, and Kolff, 1957 ; Kelemen and Kolff, 1959 ; Breakey, Woodruff, and Reus, 1961 ; Clapp, Holmes, and O'Brien, 1962 ; Walker, Garsenstein, Higgs, Lawson, and Shaldon, 1962 ; Miserez and Twiss, 1963 ; Nayman, 1963 ; Walker, Wershing, Simons, Holmes, Sitprija, and O'Brien, 1963). The reasons for dialysis and the techniques used were various (Breakey et al., 1961 ; Shaldon, Chiandussi, and Higgs, 1961 ; Nayman, 1963 ; Walker et al., 1963). One of the main problems found was that many infants and young children needed more than one haemodialysis, which increased the technical difficulties. The problems are such that quite recently Barry and Schwartz (1964) suggested peritoneal dialysis as an alternative, although they felt that haemodialysis should be used when available and practicable, or when peritoneal dialysis fails. Segar, Gibson, and Rhamy (1961), however, reporting 10 infants and small children treated by peritoneal dialysis, were dubious whether extracorporeal haemodialysis could be done on small children. Since then reports of peritoneal dialysis in a further 20 children have appeared (Etteldorf, Dobbins, Summitt, Rainwater, and Fischer, 1961 ; Etteldorf, Sweeney, Smith, Whittington, Sheffield, and Meadows, 1962 ; Gianantonio, Vitacco, Mendilaharzu, Mendilaharzu, and Rutty, 1962; Burns, Henderson, Hager, and Merrill, 1962), the first mentioned authors believing that this method will be preferred for the management of acute renal failure until extracorporeal haemodialysis has been shown to be safe and that it can be applied repeatedly over a prolonged time.

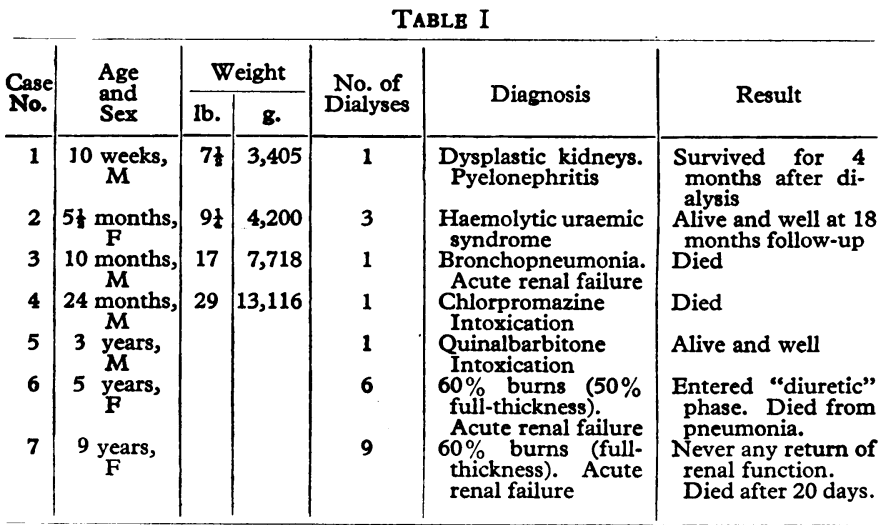

The present paper describes the simplified technique of haemodialysis used for infants and young children. The results of treating four infants aged 10 weeks to 2 years and three children aged 3 to 9 years for acute renal failure are also given (see Table I).

* Professor in Medicine, King's College Hospital, London.

t Lecturer in Medicine, King's College Hospital, London.

‡ Consultant Paediatrician. King's College Hospital, London.

\section{Method}

Under light general anaesthesia the saphenous veins were exposed in both legs in the region of the fossa ovalis and a $25-\mathrm{cm}$. nylon catheter with an external diameter of $1.34 \mathrm{~mm}$. was passed through each vein into the inferior vena cava (Fig. 1). One catheter, which acted as the return from the artificial kidney, was passed to a high level; the other was placed low down for withdrawal of blood to the artificial kidney. The infant was given $1 \mathrm{mg} . / \mathrm{kg}$. body weight of heparin intravenously, and during the dialysis the degree of heparinization was checked by the thrombin-clotting time of citrated whole blood, using Fibrindex. The clotting-time was kept at about two and a half times that of the normal control.

One-half of a Kolff disposable twin-coil artificial kidney (Kolff and Watschinger, 1956) was used for each dialysis, so that there was a reasonable approximation between the coil volume and the infant's blood-volume. The artificial kidney was primed with blood at a pressure corresponding closely to the infant's systolic blood-pressure. Careful maintenance of the intracoil pressure is essential, as minor changes in the volume of the coil can have a serious effect on the haemodynamics of the infant. For this reason the dialysis was done with the infant on weighing-scales, when even slight changes in blood-volume were then mirrored by alteration in the weight and could be quickly determined and corrected. Loss of blood into the artificial-kidney circuit was compensated by restricting the outflow to the kidney or, if necessary, adding further blood from the reservoir. The insertion of a closed paediatric chamber drip set into the circuit (see Fig. 2) enabled

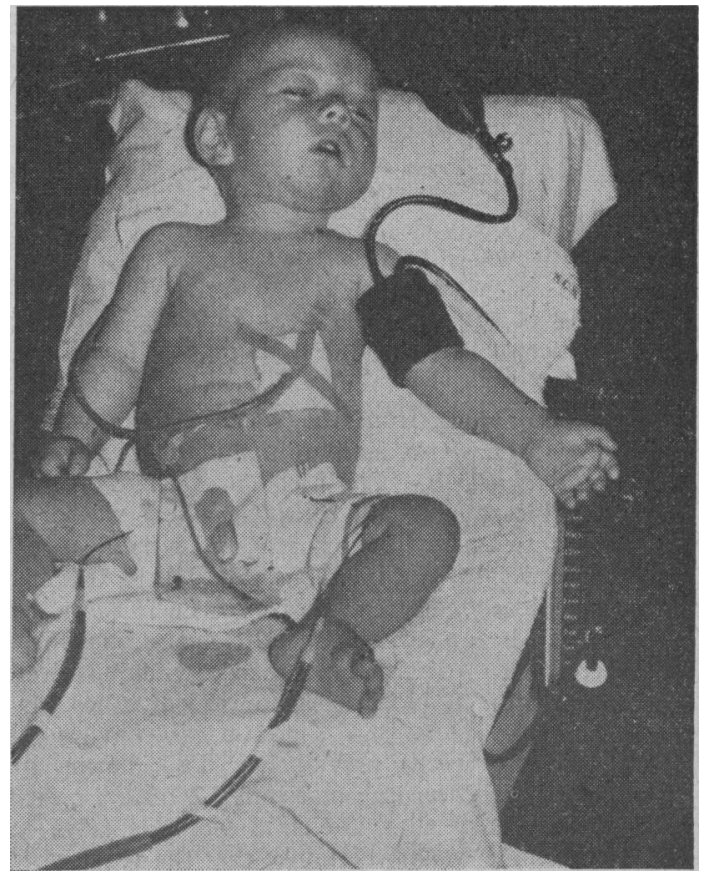

F1G. 1.-Case 3 on weighing-scales with inferior vena-cava catheters in situ. He has a disposable urine-collecting bag in place. The upper tube leads to the gastrostomy. 
close control of the volume in the whole circuit during dialysis. An overhydrated and anaemic child could be dehydrated by a known amount and then at the end of the dialysis be transfused with an appropriate amount of blood so that the haemoglobin concentration could be raised considerably before the end of a dialysis. As the total body-water of these small patients is much less than the volume of the dialysing bath, the bath was changed only once during the whole dialysis. Flow rates of $100 \mathrm{ml} . / \mathrm{min}$. were used.

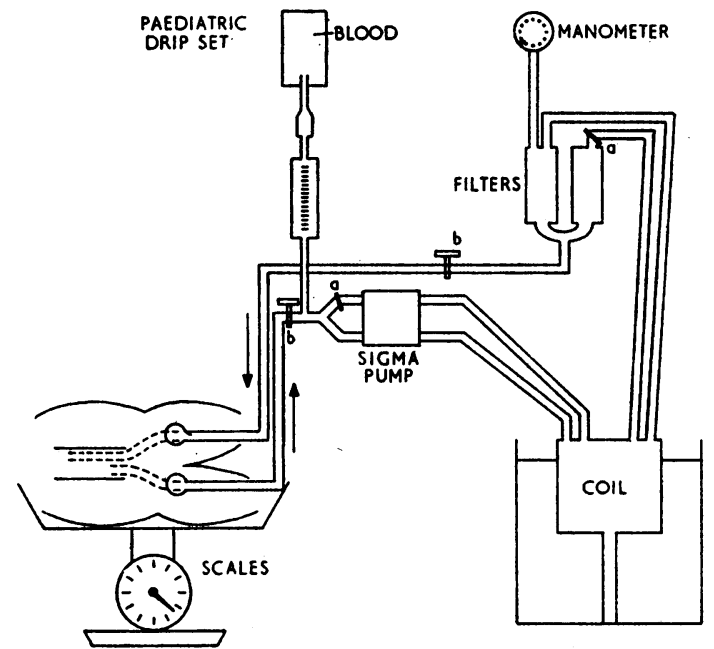

FIG. 2.-Diagrammatic scheme of circuit: $b$ refers to adjustable screw clips, $a, a$, are clips sealing off one coil. Note inflow catheter at higher level (2-3 in.: $5-7.5 \mathrm{~cm}$.) in inferior vena cava.

When more than one haemodialysis was necessary the catheters were left in situ between dialysis, and their patency was maintained by a slow infusion of either heparinized saline or Rheomacrodex through a $\mathrm{Y}$-connector at a rate of $10 \mathrm{ml}$./ 24 hours by a continuous slow injector. During the period of heparinization some blood usually oozed from the catheters, but this was easily controlled by pressure bandages. The catheters were also used for transfusion and intravenous fluid therapy where necessary. In the second patient the catheters were maintained in situ for 23 days, during which three dialyses were done. The time for dialysis varied from three to six hours. There were no infective complications. In the three older children the catheters were inserted into the radial artery and corresponding vein and were kept patent between dialyses by intermittent local heparinization.

\section{Case 1}

This male baby was first seen when 6 weeks old as his mother complained that he was failing to thrive. He was a full-term infant, weighing at birth $6 \mathrm{lb} .12 \mathrm{oz}$. $(3,060 \mathrm{~g}$.), but since then he had been reluctant to feed, and at the age of 6 weeks his weight was unchanged.

On examination, apart from the wasting there was no abnormality, but the urine showed albumin and many pus cells and a growth of Escherichia coli. The blood urea was $400 \mathrm{mg} . / 100 \mathrm{ml}$. and the plasma bicarbonate $9.8 \mathrm{mEq} / 1$. There was a good urine output. He was treated with antibiotics and intravenous therapy. He began to gain weight, and his blood urea fell to $106 \mathrm{mg} . / 100 \mathrm{ml}$. and the plasma bicarbonate rose to $16.4 \mathrm{mEq} / \mathrm{l}$. Two weeks after this treatment he began to lose weight again and his condition suddenly deteriorated. Slight generalized twitchings were noticed and at the same time a hiccup developed. Further investigation showed the haemoglobin to be $6.8 \mathrm{~g}$. $/ 100 \mathrm{ml}$., having fallen from 10.1 g. $/ 100 \mathrm{ml}$. two weeks previously. The plasma bicarbonate was now $15 \mathrm{mEq} / 1$. and serum potassium $9.2 \mathrm{mEq} / \mathrm{l}$. At this point it was thought unlikely that the child would survive more than 24 hours, but as there was no certainty that the renal condition was irreversible extracorporeal haemodialysis was felt to be the right course.
After a five-hour haemodialysis without incident the child rapidly improved. The blood urea fell from 308 to $43 \mathrm{mg} . / 100 \mathrm{ml}$. and the haemoglobin concentration was raised to $84 \%$. Following the dialysis, however, the blood urea was found four days later to be $194 \mathrm{mg} . / 100 \mathrm{ml}$., and within seven days it had reached 300 mg./100 ml. In spite of intensive antibiotic therapy the renal failure did not improve, and it was then felt that further dialysis was contraindicated. The baby, however, was clinically much better and was feeding well. He was discharged home, remaining happy and clinically well, although failing to gain weight. Some four months after dialysis he became acutely ill, developed convulsions, and died.

At necropsy both kidneys were found to be severely dysplastic with very little remaining cortical tissue. There was evidence of gross pyelonephritis and both ureters were dilated.

\section{Case 2}

This patient was born two months premature with a birth weight of $2 \frac{1}{2} \mathrm{lb}$. $(1,140 \mathrm{~g}$.). She made reasonable progress until the age of $5 \frac{1}{2}$ months, when she was admitted to another hospital with diarrhoea and vomiting and was treated with sulphonamides. She was found to be anaemic, with a haemoglobin of $40 \%$, and was then given a blood transfusion, and later intravenous electrolyte fluids. Shortly after admission she developed convulsions and became anuric. She was seen 36 hours after this, and was very ill, with marked oedema and persistent watery stools. The blood urea at this time was $183 \mathrm{mg} .100 \mathrm{ml}$., plasma bicarbonate 17 $\mathrm{mEq} / \mathrm{l}$., and plasma potassium $4 \mathrm{mEq} / 1$. The anuria persisted and the blood urea rose within 48 hours to $247 \mathrm{mg} . / 100 \mathrm{ml}$, while the plasma potassium rose to $6.1 \mathrm{mEq} / \mathrm{l}$. She was extremely ill, comatose, and twitching.

After a four-hour dialysis, which gave no difficulty, the baby's condition improved dramatically. The blood urea was then 104 mg./100 ml. and the plasma potassium $4 \mathrm{mEq} / \mathrm{l}$. (see Fig. 3). After anuria for a further seven days the blood urea was only 200 mg./100 ml., but the baby's general condition was now very poor, with frequent twitching, marked perianal excoriation, and ulcers at the corner of the mouth. A further dialysis was done without difficulty and the blood urea fell from 205 to $64 \mathrm{mg} . / 100 \mathrm{ml}$. On the third day after this second dialysis a few drops of urine were passed, but the rise in urinary volume was slow, and after a further nine days the blood urea was again $200 \mathrm{mg}$. $/ 100 \mathrm{ml}$., and the baby was ill with repeated twitching of the limbs. A third haemodialysis was therefore done, after which the blood urea fell to $72 \mathrm{mg}$./100 $\mathrm{ml}$. A few days later the urine volume began to increase and the child's condition improved steadily. Now, over a year later, she is making good progress. Recent investigation shows that only the left kidney is functioning and that there is some rotation of this kidney. The blood urea is $55 \mathrm{mg} . / 100 \mathrm{ml}$. and the plasma electrolytes are normal. The creatinine clearance is $29 \mathrm{ml} / / \mathrm{min} . / 1.73$ sq. $\mathrm{m}$., which is low. The probable diagnosis in this baby is that of haemolytic uraemic syndrome.

\section{Case 3}

This patient, the second child of healthy parents, was a male aged 10 months, weighing $5 \mathrm{lb} .4 \mathrm{oz}$. $(2,380 \mathrm{~g}$.). He had been born three weeks prematurely, but by a normal delivery. He had oesophageal atresia without a fistula, and this was corrected by a two-stage procedure, the initial stage being an oesophagostomy and gastrostomy, and the second, when he was 8 months old, was a colon transplant. At discharge after his operation he was gaining weight and having his feeds partly orally and partly by a gastrostomy tube. At this time his plasma sodium was $136 \mathrm{mEq} / 1$, plasma potassium $4.8 \mathrm{mEq} / 1$., serum bicarbonate $28 \mathrm{mEq} / 1$, plasma chloride $90 \mathrm{mEq} / 1$., and blood urea $17 \mathrm{mg} . / 100 \mathrm{ml}$. The haemoglobin concentration was $12.3 \mathrm{~g} . / 100 \mathrm{ml}$. Shortly after a three-day illness with irritability, cough, pyrexia, and moderate diarrhoea the child was readmitted as an urgency. As a result of coughing the old oesophagostomy scar had burst open. The infant was given tetracycline and penicillin. On admission he was collapsed, pyrexial (106.8 $8^{\circ}$ F.: $41.55^{\circ}$ C.), tachypnoeic but not cyanosed, and had a pulse rate of $156 / \mathrm{min}$. He had a weak cry, mild diarrhoea, and widespread crepitations in both lungs. He was dehydrated and his plasma sodium was $187 \mathrm{mEq} / 1$, plasma 
potassium $5.4 \mathrm{mEq} / 1$., plasma bicarbonate $11 \mathrm{mEq} / 1$., plasma chloride $146 \mathrm{mEq} / 1$., blood urea $351 \mathrm{mg} . / 100 \mathrm{ml}$. Serum calcium was $9.7 \mathrm{mg} . / 100 \mathrm{ml}$. and plasma inorganic phosphate $7.2 \mathrm{mg} . / 100$ $\mathrm{ml}$. The haemoglobin was $12.4 \mathrm{~g} . / 100 \mathrm{ml}$. and the white blood cell count 16,600 . The sedimentation rate was $24 \mathrm{~mm}$. in one hour. The cerebrospinal fluid was normal. In spite of energetic rehydration the child's general condition deteriorated. Two days later his plasma sodium was $158 \mathrm{mEq} / 1$, plasma potassium 6.8 $\mathrm{mEq} / 1$., plasma bicarbonate $7 \mathrm{mEq} / 1$., plasma chloride $128 \mathrm{mEq} / 1$., and blood urea $310 \mathrm{mg} . / 100 \mathrm{ml}$. In view of his clinical deterioration and the rise of his blood urea, haemodialysis was decided upon. $\mathrm{He}$ had a cyanotic attack during a three-hour dialysis, but otherwise the dialysis was uneventful. The cyanotic attack may have been due to a disequilibrium syndrome, as the dialysis rate was rapid and insufficient glucose had been added to the bath to prevent its occurrence. Table II shows the progressive improvements in his electrolytes and haemoglobin during the dialysis. Afterwards the child did not improve, and with his bronchopneumonia persisting he died in a subsequent cyanotic attack.

TABLB II.-Case 3. Biochemical Data of Haemodialysis

\begin{tabular}{|c|c|c|c|c|c|c|c|}
\hline 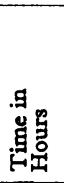 & $\begin{array}{l}\text { 劳 } \\
\text { 吾 }\end{array}$ & 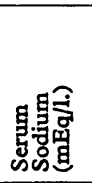 & 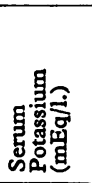 & 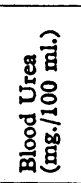 & 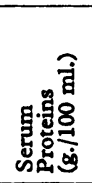 & 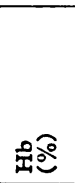 & ن) \\
\hline $\begin{array}{l}0 \\
1 \\
2 \\
3\end{array}$ & $+200 \mathrm{~g}$. & $\begin{array}{l}158 \\
148 \\
138 \\
138\end{array}$ & $\begin{array}{l}6.8 \\
5.6 \\
3.5 \\
3.3\end{array}$ & $\begin{array}{r}310 \\
190 \\
130 \\
87\end{array}$ & $\begin{array}{l}6 \cdot 9 \\
6 \cdot 3 \\
6 \cdot 3 \\
6 \cdot 1\end{array}$ & $\begin{array}{l}70 \\
75 \\
81 \\
90\end{array}$ & $\begin{array}{l}30 \\
30 \\
33 \\
37\end{array}$ \\
\hline
\end{tabular}

\section{Case 4}

This patient, a 2-year-old well-nourished child, had been brought to the casualty department after eating an unknown number of chlorpromazine tablets three hours earlier. He had been noticed to have become sleepy and ataxic at home. On admission he was conscious, his rectal temperature was $95.2^{\circ} \mathrm{F}$. $\left(35.1^{\circ} \mathrm{C}\right.$.), pulse $110 / \mathrm{min}$., blood-pressure $118 / 70$, respiration rate $16 / \mathrm{min}$. His reflexes were present and equal, although sluggish, and his pupils reacted normally to light. An intravenous drip was set up and a forced diuresis with mannitol was begun. In spite of this his condition slowly deteriorated, with falling blood-pressure, and he became less responsive to painful stimuli and remained hypothermic. As qualitative and semiquantitative tests showed chlorpromazine in the urine a haemodialysis was arranged, but before this could begin he had a cardiac arrest after inhaling vomit. The duration of the cardiac arrest was unknown but was of the order of two or four minutes. Sinus rhythm was restored by external cardiac massage, but as he failed to breathe a respirator had to be used. Because we were uncertain at this time how far his desperate clinical state was due to chlorpromazine intoxication he was given a five-hour dialysis, but with no improvement. Urine collected at the end of the dialysis showed only a trace of chlorpromazine. It was noticed that the pupillary reactions were absent from the time of the cardiac arrest.

Though he was kept alive by the respirator for a further 48 hours, in which attempts were made to raise his temperature slowly, he then had a second cardiac arrest and died. Post-mortem examination showed a total infarction of the brain, compatible with severe anoxia 48 hours earlier.

\section{Case 5}

This 3-year-old male child was admitted at 8.30 a.m. to another hospital unconscious after having eaten an unknown number of quinalbarbitone tablets, probably the previous evening. His sister was found dead in bed from a similar overdose. On admission a stomach washout failed to recover any tablets. Forced diuresis and alkalinization was started, but five hours later he was still deeply unconscious and his general condition was deteriorating, respirations becoming more laboured, and his blood-pressure was falling. On arrival at this hospital his blood-pressure was 90/70 and crepitations were heard at the base of the left lung. His blood barbiturate level was just over $1 \mathrm{mg} . / 100 \mathrm{ml}$. at this time. In view of his condition, the type of barbiturate taken, and the fact that one tragedy had already befallen the family, we decided to dialyse him. $\mathrm{He}$ regained consciousness after 3 hrs. 50 min., and when the dialysis was stopped after four hours his blood had been cleared of all barbiturate. He made an uneventful recovery and was discharged home two days later.

\section{Case 6}

A 9-year-old female was admitted to hospital with $60 \%$ fullthickness burns. Her urine output was less than $200 \mathrm{ml}$. in her first 24 hours of admission, the urine specific gravity was 1012 , and haemoglobinuria was noted. She was transferred to our care after three days because her clinical condition was then rapidly deteriorating and her blood urea and potassium were rising. On arrival her serum sodium was $114 \mathrm{mEq} / 1$., ; serum potassium 6 $\mathrm{mEq} / \mathrm{l}$. ; plasma bicarbonate $16 \mathrm{mEq} / \mathrm{l}$. ; blood urea $225 \mathrm{mg} . / 100$ ml.; total serum protein $6.8 \mathrm{~g} . / 100 \mathrm{ml}$., serum phosphorus 7.2 mg./100 ml.; serum osmolality $230 \mathrm{mOsm} / 1$; urine osmolality 278 $\mathrm{mOsm} / \mathrm{l}$; urine urea $210 \mathrm{mg} . / 100 \mathrm{ml}$; urine/plasma urea 0.8 ; urine sodium $33 \mathrm{mEq} / 1$; urine chloride $26 \mathrm{mEq} / 1$. Her haemoglobin was $8.9 \mathrm{~g} . / 100 \mathrm{ml}$. and packed cell volume $27 \%$. As she had acute renal failure secondary to severe burns a dialysis was carried out soon after arrival, followed by eight further dialyses at 48-hour intervals. The arm catheters were changed once. Throughout she was given a diet of 2,000 to 3,000 calories and containing from 40 to $60 \mathrm{~g}$. of protein. Her urine output never rose above $30 \mathrm{ml}$. in any 24 hours, and she gradually became more debilitated and died. Necropsy confirmed acute renal tubular necrosis and also showed some bronchopneumonia and a Curling's ulcer. Only the burns over the sacrum were septic.

\section{Case 7}

A 5-year-old girl was admitted to hospital with $60 \%$ burns, of which $50 \%$ were full-thickness. Her urine output fell to $50 \mathrm{ml}$. in the first 24 hours and contained albumin and glucose. Three days later she was transferred to our care. She was clinically acidotic, was drowsy, and had signs of bronchopneumonia in the right lower lobe. It is possible that she had inhaled some vomitus the day before, when she had been vomiting copiously. Her temperature was $99.2^{\circ}$ F. $\left(37.3^{\circ}\right.$ C. $)$, her haemoglobin 8.1 g./100 $\mathrm{ml}$, and P.C.V. $30 \%$. Her blood urea was $240 \mathrm{mg} . / 100 \mathrm{ml}$, urine urea $365 \mathrm{mg} . / 100 \mathrm{ml}$. ; urine plasma urea $1.5 \mathrm{~g}$., serum sodium $115 \mathrm{mEq} / 1$., serum potassium $8 \mathrm{mEq} / \mathrm{l}$., plasma bicarbonate 17 $\mathrm{mEq} / 1$., total serum protein $5.8 \mathrm{~g} . / 100 \mathrm{ml}$., urine osmalality 327 $\mathrm{mOsm} / \mathrm{l}$. Dialysis soon after admission restored her electrolytes to normal and her blood urea to $69 \mathrm{mg} . / 100 \mathrm{ml}$. Over the next 12 days, in which her daily urine output varied from 7 to $28 \mathrm{ml}$., she had a further five dialyses. On the thirteenth day her urine output rose to $150 \mathrm{ml}$. She then developed a severe right-sided pneumonia, to which high doses of antibiotics brought only temporary relief. An emergency bronchoscopy was required for an acute cyanotic attack. She then had a cardiac arrest, and, though resuscitated, died a few hours later. The post-mortem findings showed an extensive bronchopneumonia in the right lower and middle lobes and also the left lower lobe. The renal histology was that of a recovering tubular necrosis lesion.

\section{Discussion}

Although the indications for haemodialysis are now better understood, it has been little used in paediatric practice, particularly for treating the very young infant. Clinical indications for its use in infancy seem to be more important than biochemical ones. The primary reason, stressed by Clapp et al. (1962), is a deterioration in the condition of the patient as shown by progressive vomiting, lethargy, confusion, muscle-twitching, and convulsions. A serum potassium of more than $7 \mathrm{mEq} / \mathrm{l}$, an intractable acidosis of metabolic origin, and a blood urea rising to more than $200 \mathrm{mg} . / 100 \mathrm{ml}$. are additional reasons. The values are meant only as a guide, and the patient should be referred preferably before they are reached. It must be emphasized that the success of treatment by haemodialysis is considerably increased by early 
referral. When the cause of renal failure in an infant is not fully established there should be no hesitation in using haemodialysis until it has been shown that the renal lesion is irreversible. The first patient described in this paper is such an example, and illustrates that neither the size of the baby nor the age contraindicates haemodialysis.

Dialysing of patients at relatively low blood-urea levels reduces the likelihood of a disequilibrium syndrome occurring during dialysis due to raised intracellular/extracellular urea concentration ratios and related osmotic gradients (Shackman, Chisholm, Holden, and Pigott, 1962). This tendency has been further lessened by increasing the concentration of glucose in the dialysing fluid (Kennedy, Linton, Luke, Renfrew, and Dinwoodie, 1964). For similar reasons flow rates of more than $100 \mathrm{ml} . / \mathrm{min}$. should not be used when dialysing very small children, as this will cause a rapid change in the extracellular fluid compartment. By these measures the dangers of a disequilibrium syndrome occurring during dialysis in a small child are reduced and the rapid rise of the blood urea on the first day after dialysis is decreased, as shown in Fig. 3.

Repeated haemodialysis for the management of acute renal failure in the adult is well established (Teschan, Baxter, O'Brien, Freyhof, and Hall, 1960 ; Silva, Pomeroy, Rae, Rosen, and Shaldon, 1964) and that it is of value for infants and children as well is shown by our Cases 2, 6, and 7. One problem of repeated haemodialysis, which in the adult can be largely overcome by using arteriovenous shunts (Quinton, Dillard, and Scribner, 1960) or by repeated percutaneous catheterization of arteries and veins (Shaldon, Chiandussi, and Higgs, 1961), was solved in the infants treated here by bilateral saphenous-vein catheterization. This proved to be both simple and efficient. Contrary to the view expressed by Walker et al. (1962), such catheters may be left in situ for repeated haemodialysis and in addition may be used for intravenous-drip therapy. In Cases 6 and 7 haemodialysis was the only method of treatment available for their acute hypercatabolic renal failure, as severe burns over their abdominal walls precluded peritoneal dialysis. Furthermore, repeated haemodialyses at 48-hour intervals permitted both these children to be fed adequately in spite of their hypercatabolic renal failure.

Cases 4 and 5 illustrate the increasing problem of acute intoxication in infants from a wide range of hypnotic and tranquillizing drugs. Whenever doubt arises about the level of consciousness in an infant with a deteriorating clinical picture who is known to have taken such tablets, haemo-
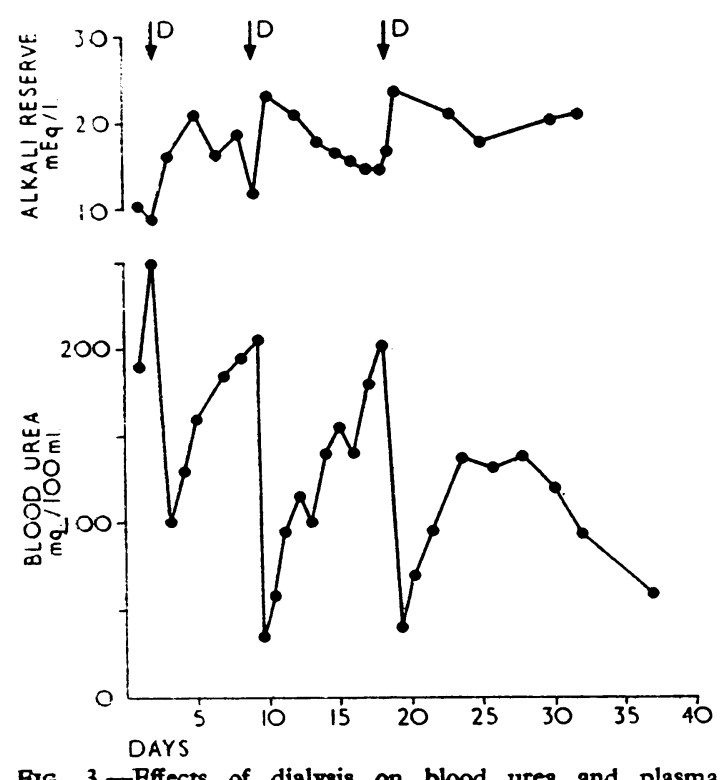

FiG. 3.- Effects of dialysis on blood urea and plasma bicarbonate in Case 2 . Note absence of rapid rise
urea on first day after each dialysis. dialysis should be considered. Many of these drugs are in part protein-bound, but it is still possible to dialyse some of the drug out of the system. In Case 4, although dialysis was effective from this point of view, recovery was not possible because of brain necrosis following cardiac arrest.

From our present experience we suggest that haemodialysis should be seriously considered for the treatment of infants and young children with acute renal failure and acute poisoning whenever it is available and practicable. At the present time there are enough artificial-kidney units in England within reach of most people for this to be possible. Our own experience with peritoneal dialysis is restricted to adults, but we feel that young infants would raise serious problems because of the lengthy treatment they would need to achieve an adequate biochemical and clinical result. The complications of peritoneal dialysis have been stressed already by Barry and Schwartz (1964). In treating overhydration and anaemia haemodialysis has more to offer.

\section{Summary}

A safe method of haemodialysis for infants and small children is described. It can be used repeatedly at short intervals, using the same catheters. From our experience in seven children whose ages ranged from 10 weeks to 9 years we regard haemodialysis by this method preferable to peritoneal dialysis.

We are grateful to Dr. Clifford Hoyle, Director of the Department of Medicine, for his interest and encouragement in preparing this paper.

AdDENDUM.-Since submitting this paper for publication three more children have been dialysed by this technique. A 20-monthold female infant was successfully dialysed for five hours after a severe overdose of imipramine. A 9-month-old baby with renal failure was dialysed for four hours ; he was found to have a congenital urethral valve and gross bilateral hydronephrosis, and he died a few days later. A $3 \frac{1}{2}$-year-old boy developed renal failure and required a four-hour dialysis; the renal failure was due to a gouty nephropathy secondary to lymphosarcoma from which he died.

\section{REFERENCES}

Barry, K. G., and Schwartz, F. D. (1964). Pediat. Clin. N. Amer., 11,

Breakey, B. A., Woodruff, M. W., and Reus, W. F. (1961). F. Urol. (Baltimore), 86, 304.

Burns, R. O., Henderson, L. W., Hager, E. B., and Merrill, J. P. (1962). New Engl. ₹. Med., 267, 1060 .

Carter, F. H., jun., Aoyama, S., Mercer, R. D., and Kolff, W. J. (1957). צ. Pediat., 51,125 .

Clapp, W. M., Holmes, J., and O'Brien, D. (1962). Amer. F. Dis. Child., $104,45$.

Etteldorf, J. N., Dobbins, W. T., Summitt, R. L., Rainwater, W. T., and Fischer, R. L. (1961). 7. Pediat., 58, 226

Sweeney, M. J., Smith, J. D., Whittington, G. L., Sheffield, J. A., and Meadows, $\ddot{R}$. W. (1962). Ibid., 60, 327.

Gianantonio, C. A., Vitacco, M., Mendilaharzu, J., Mendilaharzu, F., and Rutty, A. (1962). Ibid., 61, 660.

Kelemen, W. A., and Kolff, W. J. (1959). 7. Amer. med. Ass., 171, 530. Kennedy, A. C., Linton, A.' L., Luke, R. G., Renfrew, S., and Dinwoodie, Kennedy, A. C., Lancet, 1, 790.

Kolff, W J and Watschinger, B. (1956). 7. Lab. clin. Med., 47, 969.

Kolf, W. J., and Watschinger, B. (1956). F. Lab. clin. Med., ${ }^{47,}$ A 969. ateer, F. M., Greenman,

Merrill, J. P., Smith, S., Callahan, E. J., and Thorn, G. W. (1950). 7. clin. Invest., 29, 425 .

Miserez, J., and Twiss, E. E. (1963). Belg. T. Geneesk., 19, 1323.

Nayman, J. (1963). Brit. med. F., 2, 160

Quinton, W. Dillard, D., and Scribner, B. H. (1960). Trans. Amer. Soc. Artif. intern. Organs, 6, 104.

Segar, W. E., Gibson, R. K., and Rhamy, R. (1961). Pediatrics, 27, 603. Shackman, R. Chisholm, G. D., Holden, A. J., and Pigott, R. W. (1962) Brit. med. \%., 2, 355.

Shaldon. S., Chiandussi, L., and Higgs, B. (1961). Lancet, 2, 857.

Shaldon, S., Chiandussi, L., and Higgs, B. (19., Rosen, S. M., and Shaldon, S. (1964). Brit. med. F., 2, 407.

Teschan, P. E., Baxter, C. R., O'Brien, T. F., Freyhof, J. N., and Hall, W. H. (1960). Ann. intern Med., 53, 992.

Walker, C. H. M., Wershing, J. M., Simons, S. L., Holmes, J. H., Sitprija, V., and O'Brien, D. (1963). Amer. ¥. Dis. Child., 106, 479.

Wakker, J. G., Garsenstein, M. Higgs, B., Lawson, T. R., and Shaldon, S. (1962). Arch. Dis. Childh., 37, 578 . 